\title{
Biological Activity of Metal-edds (ethylenediaminedisuccinate) Complexes in K562 and PBMC Cells
}

\author{
Natália J. S. Costa, ${ }^{a}$ Szulim B. Zyngier, ${ }^{b}$ Cíntia R. Bombardieri, ${ }^{b}$ Juliana S. Kuribayashi, ${ }^{b}$ \\ Maristela M. de Camargo ${ }^{b}$ and Breno P. Espósito ${ }^{* a}$
}

${ }^{a}$ Instituto de Química, Universidade de São Paulo, Av. Lineu Prestes 748 sala 1265, 05508-000 São Paulo-SP, Brazil

${ }^{b}$ Instituto de Ciências Biomédicas, Universidade de São Paulo, Av. Lineu Prestes 2415, 05508-000 São Paulo-SP, Brazil

\begin{abstract}
O efeito do ácido $S, S$-etilenodiaminodi-succínico (edds) na supressão da oxidação do ácido ascórbico catalisada por metais $(\mathrm{Mn}, \mathrm{Fe}, \mathrm{Co}, \mathrm{Ni}, \mathrm{Cu}, \mathrm{Zn}$ ) foi testado in vitro através da oxidação da sonda fluorescente cloreto de 1,2,3-diidrorodamina. A atividade pró-oxidante do ferro não foi totalmente suprimida, mesmo sob excesso molar de quatro vezes do ligante. $\mathrm{O}$ efeito do meio de cultura na toxicidade dos complexos para células mononucleares do sangue periférico (PBMC) e da linhagem K562 foi estudado. A citotoxicidade de Fe-edds foi abolida na presença de Trolox ou de proteínas do soro. Os prováveis mecanismos de toxicidade celular foram investigados através do bloqueio de transportadores de monocarboxilatos (MCT) e estudos de ciclo celular por citometria de fluxo. Células tratadas com os complexos metálicos e com o ácido $\alpha$-ciano-4-hidroxicinâmico, um conhecido bloqueador de MCT, mostraram recuperação de viabilidade, sugerindo que esses transportadores possam estar envolvidos na internalização dos complexos metal-edds. $\mathrm{O}$ ácido livre promoveu a parada do ciclo celular na fase G0/G1 (PBMC) ou S (K562), sugerindo dano direto ao DNA ou interferência na sua duplicação.
\end{abstract}

The effect of $S, S$-ethylenediaminedisuccinic acid (edds) on the quenching of metal-catalyzed (metal $=\mathrm{Mn}, \mathrm{Fe}, \mathrm{Co}, \mathrm{Ni}, \mathrm{Cu}, \mathrm{Zn}$ ) oxidation of ascorbic acid was tested in vitro via oxidation of the fluorescent probe 1,2,3-dihydrorhodamine dihydrochloride. The pro-oxidant activity of iron was not fully suppressed, even at a four-fold molar excess of the ligand. The effect of serum on the toxicity to peripheral blood mononuclear cells (PBMC) and K562 cells was investigated. The cytotoxic effect of Fe-edds was abrogated in the presence of Trolox or serum proteins. The probable pathways of cell toxicity were investigated through blocking of the monocarboxylate transporters (MCT) in association with cell cycle studies by flow cytometry. Cells treated with metal complexes and $\alpha$-cyano-4-hydroxycinnamic acid, a known MCT inhibitor, showed recovery of viability, suggesting that MCT proteins may be involved in the internalization of metal-edds complexes. The free acid induced cell cycle arrest in G0/G1 (PBMC) and S (K562) phases, suggesting direct DNA damage or interference in DNA replication.

Keywords: K562, edds, antitumor, pro-oxidant, cell cycle, PBMC

\section{Introduction}

Ethylenediamminedisuccinic acid (edds) was the first natural aminopolycarboxylic acid discovered, isolated from a culture of Amycolatopsis orientalis. It was first detected due to its ability to inhibit $\mathrm{Zn}^{2+}$-dependent phospholipase $\mathrm{C}$ activity. Edds has two chiral carbon atoms, resulting in three possible stereoisomers $[S, S],[R, S]$ and $[R, R] .{ }^{1,2}$

Technical applications of edds usually involve remediation of soils contaminated with heavy metals, either in

\footnotetext{
*e-mail: breno@iq.usp.br
}

extraction columns, ${ }^{3}$ induced in situ phytoextraction ${ }^{4,5}$ or soil washing in permeable barriers. ${ }^{5,6}$ Comparative tests involving $[S, S]$-edds and edta (ethylenediaminetetraacetic acid) were performed to determine their relative efficiencies in inducing phytoextraction of heavy metals; $[S, S]$-edds was more efficient for $\mathrm{Cu}^{2+}$ removal, while edta removed $\mathrm{Pb}^{2+}$ preferentially. However, since edds is more biodegradable than edta, the former has been recommended as a potential replacement for the latter in environmental applications. ${ }^{7,8}$ The $S, S$ stereoisomer was found to give rise to slightly more stable complexes (around $0.3-0.5 \log$ units) than the $R, S$ isomer, suggesting a small stereospecificity in metal 
coordination. ${ }^{9}[S, S]$-edds is also efficient for radiochemical decontamination. ${ }^{10}$

There are relatively few studies addressing the biological activity of this chelator. It is toxic to algae ${ }^{11}$ and inhibits the formation of biofilms by Xylella fastidiosa.$^{12}$ Its antiviral activity in vitro and in vivo, which has been demonstrated against cytomegaloviruses, is probably due to inhibition of ribonucleotide reductase activity. ${ }^{13}$

Metal complexes of $[S, S]$-edds are also highly biodegradable,${ }^{14}$ but there are no reports of their behavior when in biological medium. Their stability is comparable to that of edta-containing analogues; therefore, they might be involved in altered metal mobilization and availability when present in the environment. An understanding of the biological activity of metal-edds complexes is important both for decontamination applications and for the development of metallopharmaceuticals.

In this paper, we report the biological and pro-oxidant activities of several $\mathrm{M}-[S, S]$-edds complexes $\left(\mathrm{M}=\mathrm{Fe}^{3+}\right.$, $\mathrm{Co}^{2+}, \mathrm{Ni}^{2+}, \mathrm{Zn}^{2+}, \mathrm{Cu}^{2+}, \mathrm{Mn}^{2+}$ ) in $\mathrm{K} 562$ and PBMC cells. Also, in this study the protective effect of serum proteins against toxicity was verified. We found that the oxidant activity of iron was not fully inhibited by edds, but Fe-edds cell toxicity was halted by the presence of serum and Trolox, which acted as antioxidants. In the absence of medium, blocking of membrane monocarboxylate transporters decreased K562 mortality caused by Fe- and Co-edds complexes, which implies that this transport route may be used for the internalization of these complexes. Free edds induced cell cycle arrest in G0/G1 (PBMC) and S (K562) phases, indicating DNA damage or interference with DNA replication.

\section{Experimental}

Abbreviations: edds, S,S-ethylenediamminedisuccinic acid; PBMC, Peripheral Blood Mononuclear Cells; 4-HCA, $\alpha$-cyano-4-hydroxycinnamic acid.

\section{Reagents}

The following reagents were used without further purification: $\mathrm{MnSO}_{4} \cdot \mathrm{H}_{2} \mathrm{O}, \mathrm{FeSO}_{4} \cdot 7 \mathrm{H}_{2} \mathrm{O}, \mathrm{CuSO}_{4} \cdot 5 \mathrm{H}_{2} \mathrm{O}$, $\mathrm{NiSO}_{4} \cdot 6 \mathrm{H}_{2} \mathrm{O}, \mathrm{ZnSO}_{4} \cdot 7 \mathrm{H}_{2} \mathrm{O}, \mathrm{CoSO}_{4} \cdot 7 \mathrm{H}_{2} \mathrm{O}$, edta disodium salt, nitrilotriacetic acid (nta), L-ascorbic acid, $\mathrm{NaCl}$ (Cromoline, Diadema, Brazil); Octaquest ${ }^{\circledR}$ E30 ([S,S]-edds trisodium salt; The Associated Octel Co., UK); Trolox, Chelex $^{\circledR}, \alpha$-cyano-4-hydroxycinnamic acid (4-HCA; SigmaAldrich, St. Louis, MO); N-2-hydroxyethylpiperazine- $N$ '2-ethanesulfonic acid (HEPES; Vetec, Rio de Janeiro, Brazil); 1,2,3-dihydrorhodamine dihydrochloride (DHR;
Biotium, Hayward, CA). Ascorbic acid and DHR were prepared as concentrated stocks of $8 \mathrm{mmol} \mathrm{L}^{-1}$ in water or $50 \mathrm{mmol} \mathrm{L}^{-1}$ in dimethyl sulfoxide, respectively, kept frozen as aliquots and thawed immediately before use. HEPES-Buffered Saline (HBS) was prepared with $20 \mathrm{mmol}$ $\mathrm{L}^{-1}$ HEPES, $150 \mathrm{mmol} \mathrm{L}^{-1} \mathrm{NaCl}$, pH 7.4. Phosphate Buffer Saline (PBS) was prepared with $0.14 \mathrm{~mol} \mathrm{~L}^{-1} \mathrm{NaCl} ; 2.6$ mmol L-1 $\mathrm{NaH}_{2} \mathrm{PO}_{4} \cdot \mathrm{H}_{2} \mathrm{O}$ and $7.4 \mathrm{mmol} \mathrm{L}-1 \mathrm{Na}_{2} \mathrm{HPO}_{4} \cdot 7 \mathrm{H}_{2} \mathrm{O}$, $\mathrm{pH}$ 7.4. When required, metal-free HBS was prepared by treating the solution with $\mathrm{Chelex}^{\circledR}$ resin $\left(10 \mathrm{mg} \mathrm{mL}^{-1}\right)$.

\section{Instruments}

Spectra were recorded using a Shimadzu UV-1650PC (UV-Visible) or a Bomem MB-100 spectrophotometer in $\mathrm{KBr}$ pellets (infrared). Fluorescence measurements were performed in a Tecan GENios microplate reader (Tecan, Austria; $\lambda_{\text {exc }}=485 \mathrm{~nm} ; \lambda_{\mathrm{em}}=535 \mathrm{~nm}$ ) in 96-well microplates (TPP, Switzerland). Flow cytometry measurements were carried out using a FACS Calibur (Becton Dickinson, CA) with laser excitation at $488 \mathrm{~nm}$.

\section{Complexes}

M-edds $\left(\mathrm{M}=\mathrm{Mn}^{2+}, \mathrm{Fe}^{2+}, \mathrm{Co}^{2+}, \mathrm{Ni}^{2+}, \mathrm{Cu}^{2+}\right.$ or $\left.\mathrm{Zn}^{2+}\right)$ complexes were prepared once a week through the dissolution of the appropriate mass of metal salt in a $0.5 \mathrm{~mol} \mathrm{~L}^{-1}$ edds aqueous solution to give a 1:1 metal:edds final stoichiometry. Stock solutions were not kept for longer than one week due to the development of mold.

\section{Pro-oxidant activity}

The ability of edds to prevent the metal-catalyzed oxidation of ascorbic acid was assessed by a slight modification of a previously reported method. ${ }^{15}$ Metal-nta stock solutions were prepared by mixing $100 \mathrm{mmol} \mathrm{L}^{-1}$ nta (titrated to $\mathrm{pH}$ 7.0 with $\mathrm{NaOH}$ ) with the appropriate mass of metal salt to produce a metal:nta molar ratio of 1:10. The objective of this procedure was to prevent metal hydrolysis by protecting the metal ion in a well-defined chelate. The nitrilotriacetic acid was chosen as the protective ligand because the formation constants of its metal complexes are lower than those of metal-edds analogues, ${ }^{16}$ and thus the metal can be transferred to edds in the reaction medium.

The metal-nta solutions were further diluted in water to give a final metal concentration of $5 \mu \mathrm{mol} \mathrm{L} \mathrm{L}^{-1} .20 \mu \mathrm{L}$ aliquots of these solutions were then transferred, in duplicate, to a microplate and mixed with $20 \mu \mathrm{L}$ aliquots of different edds solutions ([edds $]_{\text {final }}=0,2.5,5,10$ or $20 \mu \mathrm{mol} \mathrm{L} \mathrm{L}^{-1}$ ). The mixtures were then immediately mixed with to $180 \mu \mathrm{L}$ of 
a fluorogenic solution consisting of $40 \mu \mathrm{mol} \mathrm{L}-1$ ascorbic acid and $50 \mu \mathrm{mol} \mathrm{L}^{-1} \mathrm{DHR}$ in metal-free HBS. Fluorescence reading was performed at $37^{\circ} \mathrm{C}$ for 40 minutes.

\section{Cell studies}

In vitro studies were performed using K562 human leukemia cells cultured in complete RPMI-1640 medium (RPMI, 2\% glutamax, $40 \mathrm{mg} \mathrm{L}^{-1}$ gentamicine, $10 \%$ heat-inactivated fetal calf serum) at $37{ }^{\circ} \mathrm{C}$ and $5 \%$ $\mathrm{CO}_{2}$. Cell viability was determined through Trypan Blue counting. Peripheral blood mononuclear cells (PBMC) were obtained from healthy donors by centrifugation in a Ficoll-Paque ${ }^{\mathrm{TM}}$ PLUS gradient (GE Biosciences). Briefly, blood samples were diluted 1:1 with PBS and layered over Ficoll-Paque ${ }^{\mathrm{TM} P L U S}$. After centrifugation at $900 \times g$ for 30 minutes at $20{ }^{\circ} \mathrm{C}, \mathrm{PBMC}$ were harvested at the interface, washed in PBS and immediately processed.

To assess the toxicity of the metal-edds complexes and the effect of serum proteins, triplicates of $1.0 \mathrm{~mL}$ of a cell suspension in either complete RPMI medium or PBS ( $c a$. $10^{6}$ cells $\mathrm{mL}^{-1}$ ) were transferred into a 24-well plate and treated with $\mathrm{M}$-edds solutions at final concentrations of 0 , 10,100 and $1000 \mu \mathrm{mol} \mathrm{L}^{-1}$ of M-edds. After 24 hours of incubation, cells were centrifuged at $500 \times g$ for 3 minutes and resuspended in 50\% Trypan Blue in PBS. Live and dead cells were counted.

The inhibition of cell monocarboxylate transporters (MCT) was assessed in a similar setup, except that cells were kept in PBS and treated with $10 \mathrm{mmol} \mathrm{L}^{-1} 4-\mathrm{HCA}$ for $24 \mathrm{~h}$ before the addition of $100 \mu \mathrm{mol} \mathrm{L}^{-1} \mathrm{M}$-edds complexes $(\mathrm{M}=\mathrm{Fe}, \mathrm{Ni}, \mathrm{Co})$. Controls with no 4-HCA were kept under the same conditions. To assess the role of prooxidant activity in cell viability, cells were kept in PBS and treated with $100 \mu \mathrm{mol} \mathrm{L}-1$ of the antioxidant Trolox immediately before the addition of Fe-edds (final concentrations: 100 and $\left.1000 \mu \mathrm{mol} \mathrm{L}{ }^{-1}\right)$. Controls had no Trolox added. Analysis of variance (ANOVA, $p<0.05$ ) followed by group comparison using Fisher's LSD test (Protected
t-Test) were performed with GB-STAT ${ }^{\circledR}$ software (version 9.0; Dynamic Microsystems).

For the flow cytometry experiments, the cells $(1.0 \mathrm{~mL}$ aliquots; $\left.1.0 \times 10^{6} \mathrm{~mL}^{-1}\right)$ were incubated in complete RPMI for $1 \mathrm{~h}$ at $37^{\circ} \mathrm{C}$ and $5 \% \mathrm{CO}_{2}$ in the presence of $10 \mu \mathrm{mol} \mathrm{L}{ }^{-1}$ $\mathrm{M}$-edds or edds alone. Cells were then centrifuged and stained with propidium iodide (PI) in hypotonic fluorochrome solution (50 $\mu \mathrm{g} \mathrm{mL}^{-1} \mathrm{PI}$ in $0.1 \%$ sodium citrate, $0.1 \%$ Triton X-100) and PI fluorescence was measured by flow cytometry (FACS Calibur, Becton Dickinson, San Jose, CA). Data were acquired using CellQuest (BD, CA) and analyzed with FlowJo (TreeStar, CA) software. The percentage distribution of the cell population among the different phases of the cell cycle was calculated using the Watson Pragmatic method (G2 defined as 2×G1).

\section{Results and Discussion}

\section{Complexes}

The spectroscopic data indicated that edds forms stable, hexadentate complexes with most transition metals. The infrared analysis of the crystals obtained by recrystallization (Table 1) showed the characteristic displacement of the asymmetric carboxylate stretching to lower frequencies for the complexes, as previously established, ${ }^{17,18}$ implying that this group is involved in the coordination to the metal. UV-visible measurements of aqueous solutions of $\left[\mathrm{M}\left(\mathrm{H}_{2} \mathrm{O}\right)_{6}\right]^{2+}$ and $\mathrm{M}$-edds $(\mathrm{M}=\mathrm{Co}, \mathrm{Ni}, \mathrm{Cu} ;[\mathrm{M}]=[$ edds $]=$ $5 \mu \mathrm{mol} \mathrm{L}{ }^{-1}$ ) were also consistent with the formation of complexes, with the displacement of the absorption maxima $\left(\lambda_{\text {abs }}\right)$ to $492 \mathrm{~nm}\left(\right.$ Co-edds $\left.{ }^{19}\right), 369$ and $583 \mathrm{~nm}\left(\right.$ Ni-edds $\left.{ }^{20}\right)$ and $670 \mathrm{~nm}\left(\mathrm{Cu}\right.$-edds $\left.{ }^{21}\right)$. Upon oxidation to $\mathrm{Fe}^{\mathrm{III}}$ during complex formation, Fe-edds solutions turn yellowishbrown and display a small shoulder at $c a .490 \mathrm{~nm}$.

\section{Pro-oxidant activity}

The DHR probe (non-fluorescent in its reduced form) undergoes unspecific oxidation and develops fluorescence

Table 1. Main infrared absorptions $\left(\mathrm{cm}^{-1}\right)$ for metal-edds complexes

\begin{tabular}{|c|c|c|c|c|c|c|}
\hline \multirow{2}{*}{ Complex } & \multicolumn{3}{|c|}{ Literature $^{18}$} & \multicolumn{3}{|c|}{ Present study } \\
\hline & $v(\mathrm{C}-\mathrm{O})$ as & $v(\mathrm{C}-\mathrm{O}) \mathrm{s}$ & $v(\mathrm{C}-\mathrm{N})$ & $v(\mathrm{C}-\mathrm{O})$ as & $v(\mathrm{C}-\mathrm{O}) \mathrm{s}$ & $v(\mathrm{C}-\mathrm{N})$ \\
\hline $\mathrm{Mn}^{\mathrm{II}}$-edds & 1630,1590 & 1400 & 1060,1030 & 1630 & 1394 & 1032 \\
\hline $\mathrm{Fe}^{\mathrm{III}}$-edds & 1635 & 1400 & 1080,1060 & 1635 & 1391 & 1060,1106 \\
\hline $\mathrm{Co}^{\mathrm{II}}$-edds & - & - & - & 1609 & 1395 & 1061,1107 \\
\hline $\mathrm{Ni}^{\mathrm{II}}$-edds & 1680,1570 & 1410 & 1115,1085 & 1603 & 1403 & 1056,1112 \\
\hline $\mathrm{Cu}^{\mathrm{II}}$-edds & 1610 & 1400 & 1115,1090 & 1608 & 1396 & 1063,1108 \\
\hline $\mathrm{Zn}^{\mathrm{II}}$-edds & 1630,1595 & 1400 & 1060,1035 & 1605 & 1400 & - \\
\hline
\end{tabular}


in an oxidant concentration-dependent manner. In our experimental setting, the slope of a kinetic fluorescence curve is directly dependent on the amount of free radicals produced during the metal-catalyzed oxidation of ascorbic acid in the reaction media. Metal ions, such as $\mathrm{Fe}^{3+}$ and $\mathrm{Cu}^{2+}$, are known to catalyze this reaction ${ }^{22,23}$ when in their free form, but a plethora of chelators might decrease their activity provided that they can bind to the metal through available coordination sites. ${ }^{24}$ Thus, we aimed to verify whether edds might behave as an antioxidant in this metalpromoted oxidation by removing the metal through the formation of a stable chelate.

(a)

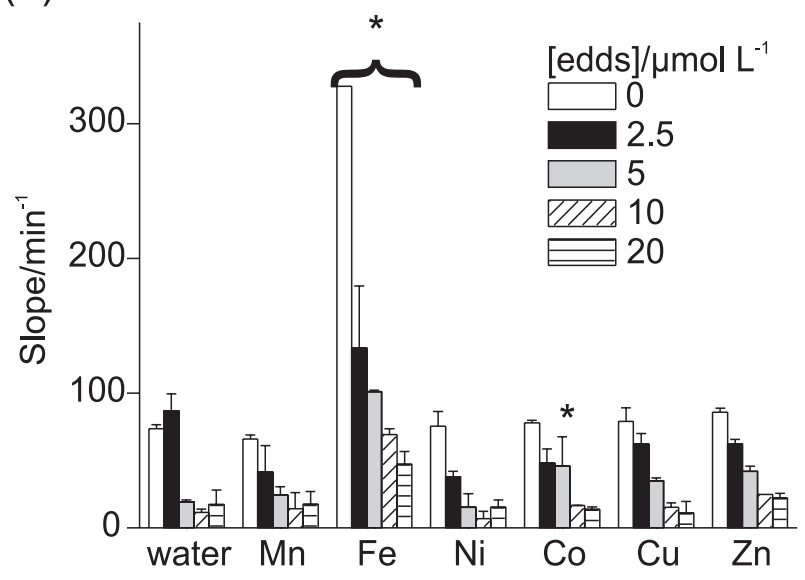

(b)

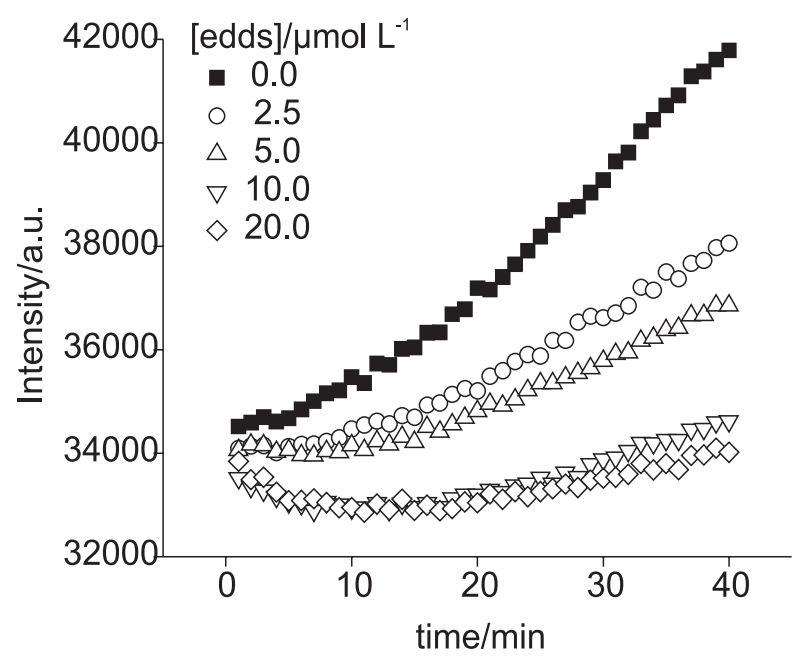

Figure 1. $\mu \mathrm{mol} \mathrm{L} \mathrm{L}^{-1}$. Asterisks indicate significant differences from the control (water) according to analysis of variance (ANOVA, $p<0.05$ ) and comparison of the groups using Fisher's LSD test (Protected t-Test). (b) Example of a typical fluorescence kinetic curve. The figure depicts fluorescence intensity (in arbitrary units) versus time for Fe $(5 \mu \mathrm{mol}$ $\left.\mathrm{L}^{-1}\right)$ in the presence of different concentrations of edds. The slopes were calculated from $t=15 \mathrm{~min}$ onwards.
We observed that, except for Fe, all tested metals behaved similarly to the control with respect to the decrease in the rate of ascorbate oxidation versus [edds] (Figure 1). Traces of iron present in the buffer may be responsible for the apparent "redox activity" of water alone, which subsided with increasing [edds]. However, this should not exclude the occurrence of important redox reactions promoted by other cations, since the experimental setting was optimized for clinical evaluation of redox-active iron. ${ }^{15}$ As expected, the $\mathrm{Zn}$-edds complex did not show any redox activity.

"Free" iron displays high redox activity (Figure 1). Interestingly, iron-catalyzed ascorbate oxidation was not totally suppressed, even at a four-fold molar excess of edds. Two important conclusions might be drawn from this observation. First, edds is not an antioxidant per se. Second, iron chelates such as Fe-edta, which present at least one free coordination site, are known to promote the formation of reactive oxygen species. ${ }^{24}$ Indeed, Fe-edta is an excellent catalyst of ascorbate oxidation. ${ }^{25}$ Our observations indicate that this is also the case for Fe-edds, since $\mathrm{Fe}^{3+}$ tends to form less stable bonds with relatively soft bases like the $\mathrm{N}$ atoms of edds, which implies that these groups are readily replaced by solvent molecules, the metal remaining redox-active. On the other hand, Kovaleva et al. ${ }^{18}$ identified a peak at $1725 \mathrm{~cm}^{-1}$ attributed to the $\mathrm{v}(\mathrm{C}=\mathrm{O})_{\text {as }}$ of a free carboxylic group in Fe-edds. They suggested that the nitrogen atoms, three oxygen atoms from the carboxyl groups and one water molecule form the coordination sphere of $\mathrm{Fe}^{3+}$ in Fe-edds. We did not identify this particular stretching frequency in our experiments (Table 1). Kovaleva's model also explains the persistence of available positions (the water molecule) through which ascorbate could interact with $\mathrm{Fe}$ and initiate a cascade of oxidation. It should be noted that complete blocking of all available coordination sites, in order to prevent unwanted redox side-reactions in vivo, is one of the requisites for molecules employed in iron chelation therapy. ${ }^{15}$

\section{Cell studies}

Initially, we compared the effect of the incubation time of M-edds complexes on K562 and PBMC viability (Figure 2 ). The tumor line was less resistant to the toxic effects of some of the complexes (Fe-edds, Co-edds and Ni-edds) after $24 \mathrm{~h}$ when compared to PBMC. In fact, virtually no toxic effects were observed for non-tumoral ex-vivo cells even at high M-edds concentrations and prolonged exposure. Edds is known to capture $\mathrm{Zn}^{2+}$ in biological media, ${ }^{2}$ therefore it can compete with enzymes for this metal and induce loss of enzymatic functions. Curiously, free edds did 

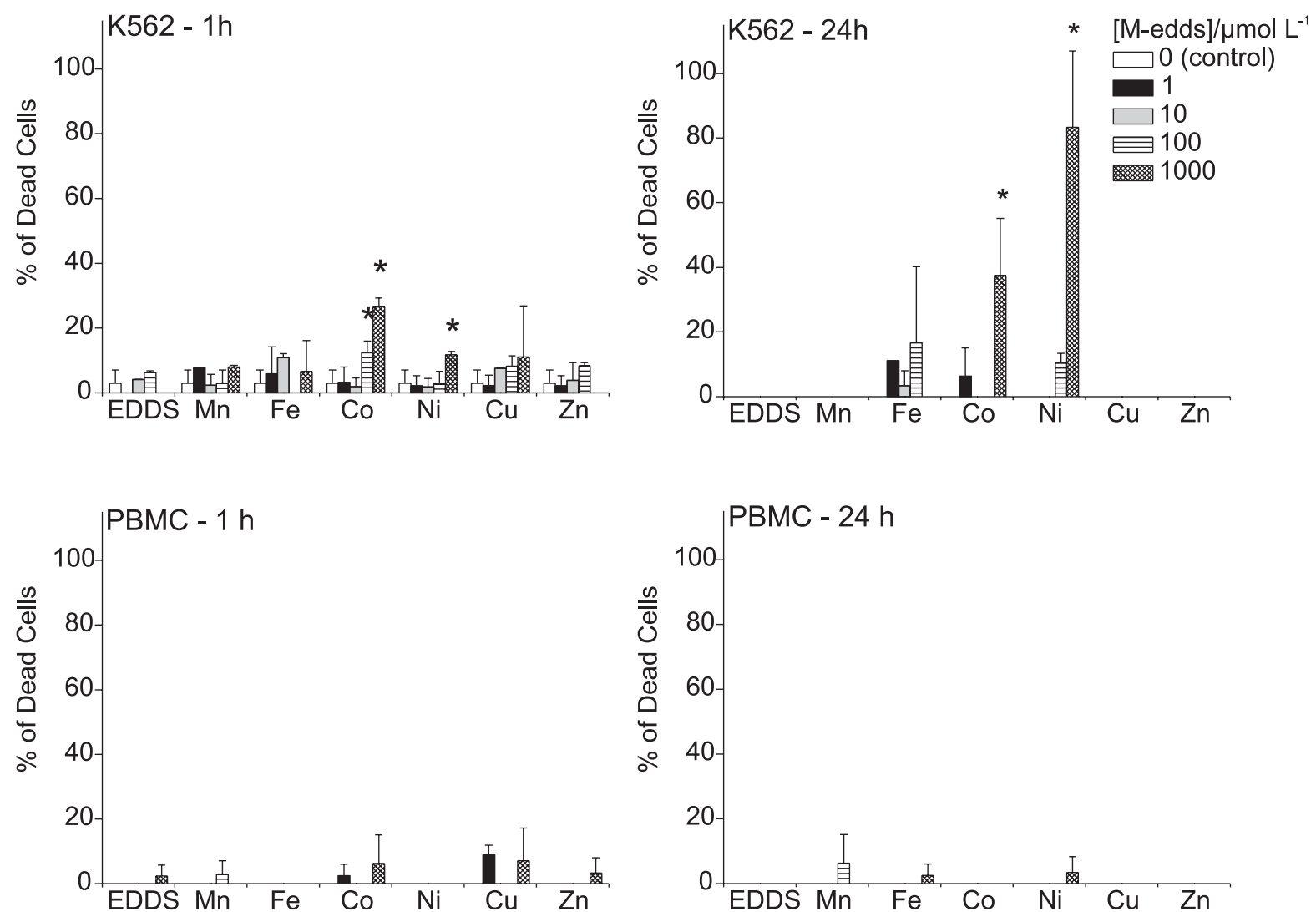

Figure 2. Cytotoxicity of M-edds complexes to K562 and PBMC cells after 1 and $24 \mathrm{~h}$ incubation (mean \pm S.D.) in complete RPMI medium. Asterisks indicate significant differences from the control according to analysis of variance (ANOVA, $p<0.05$ ) and comparison of the groups using Fisher's LSD test (Protected t-Test). The Trypan Blue exclusion test was used to evaluate cell viability.

not show high toxicity to the cells (Figure 2), indicating that the toxicity of M-edds complexes, when present, depends mainly on the nature of the metal being transported into the cell. Iron, cobalt and nickel complexes were the most toxic to K562 cells, albeit at the relatively high concentrations of 100 and $1000 \mu \mathrm{mol} \mathrm{L}^{-1}$. This observation supports previous claims that edds is a useful chelator to reduce metal contamination risks, ${ }^{1}$ but at the same time indicates that some of the M-edds complexes could be effective metallodrugs for tumor chemotherapy.

Since the toxicity of metallodrugs in vivo is critically determined by the outcome of their interactions with plasma proteins, ${ }^{26}$ and serum deprivation may stress cells leading to higher susceptibility to toxicants and apoptosis, we conducted a set of experiments to assess the toxicity of M-edds complexes to K562 in the presence and absence of serum (Figure 3 ).

As anticipated, all control groups displayed higher mortality when treated with PBS only (compare right upper panel of Figure 2 with Figure 3). Also, Zn-edds was more toxic under this condition than in the presence of the culture medium. Interestingly, Fe-edds displayed a greatly increased rate of mortality in the absence of serum. Proteins such as albumin have extensive antioxidative effects in vivo, and we previously noted (Figure 1) that Fe-edds is

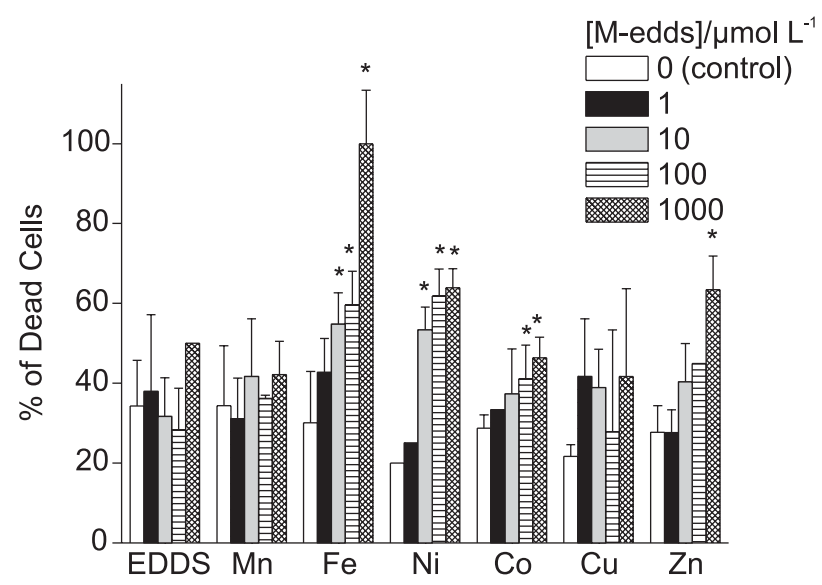

Figure 3. Cytotoxicity of M-edds complexes to K562 cells after $24 \mathrm{~h}$ incubation in PBS (mean \pm S.D.). Asterisks indicate significant differences from the control according to analysis of variance (ANOVA, $p<0.05$ ) and comparison of the groups using Fisher's LSD test (Protected t-Test). The Trypan Blue exclusion test was used to evaluate cell viability. 
an effective pro-oxidant of ascorbate (and, presumably, of other biological substrates). Therefore, we hypothesized that the observed decreased viability of cells treated with Fe-edds in PBS might be the result of an oxidative aggression towards the cells, as observed by other researchers for other iron complexes. ${ }^{27,28}$ To test this point, we conducted a comparative study on the viability of cells challenged with Fe-edds, using cells which had been treated or not treated with the antioxidant Trolox in the absence of serum (Figure 4). The presence of the antioxidant suppressed toxicity even at the highest concentrations of Fe-edds.
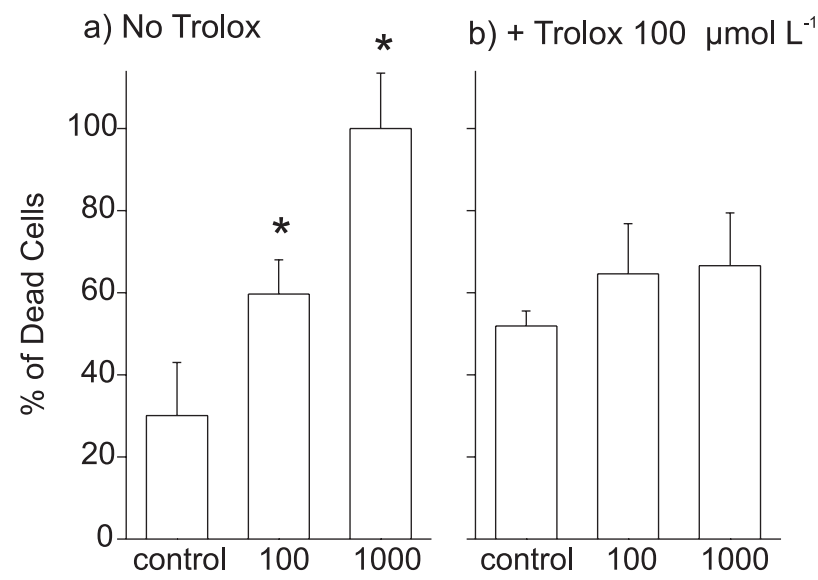

Figure 4. Effect of $100 \mu \mathrm{mol} \mathrm{L}-1$ Trolox on K562 cell viability after treatment with $100 \mu \mathrm{mol} \mathrm{L}-1$ and $1000 \mu \mathrm{mol} \mathrm{L}^{-1}$ (mean \pm S.D.) of Fe-edds in PBS. Asterisks indicate significant differences from the control according to analysis of variance (ANOVA, $p<0.05$ ) and comparison of the groups using Fisher's LSD test (Protected t-Test). The Trypan Blue exclusion test was used to evaluate cell viability.

To gain some insight into the mechanisms of biological action, the cell toxicity studies in the absence of serum were repeated in the presence and absence of 4-HCA, a known inhibitor of membrane monocarboxylate transporter (MCT) proteins. ${ }^{29-31}$ This family of proteins is involved in the transport of short chain carboxylates (pyruvate, lactate), ketone bodies and hormones through several biological interfaces. ${ }^{32}$ This test was not performed with cells grown in complete RPMI due to the fact that, as previously observed, cell toxicity in this case was difficult to observe.

We observed (Figure 5) that 4-HCA-treated cells resisted $\mathrm{Fe}$ - and Co-edds toxicity. Ni-edds did not show a similar recovery, probably because the concentration was too high to verify the role of MCT blocking. This indicates that membrane monocarboxylate transporters may be required for the internalization of these metal complexes. Our results do not rule out other internalization routes such as passive diffusion. However, for the anionic M-edds complexes, passive diffusion through cell membranes is unlikely, since none of these complexes showed a detectable octanol-water partition (data not shown). A previous report accounted for the facilitated transport of aluminum citrate by MCT1, suggesting that the transporter would recognize a free citrate carboxylate. ${ }^{33}$ However, it should be noted that potential metal ligands, such as acetoacetate, which lack this free carboxylic acid motif, are recognized MCT substrates. ${ }^{32}$ To our knowledge, the present work is the first report of complexes lacking a free carboxylic function in the chelating agent being transported by MCTs.

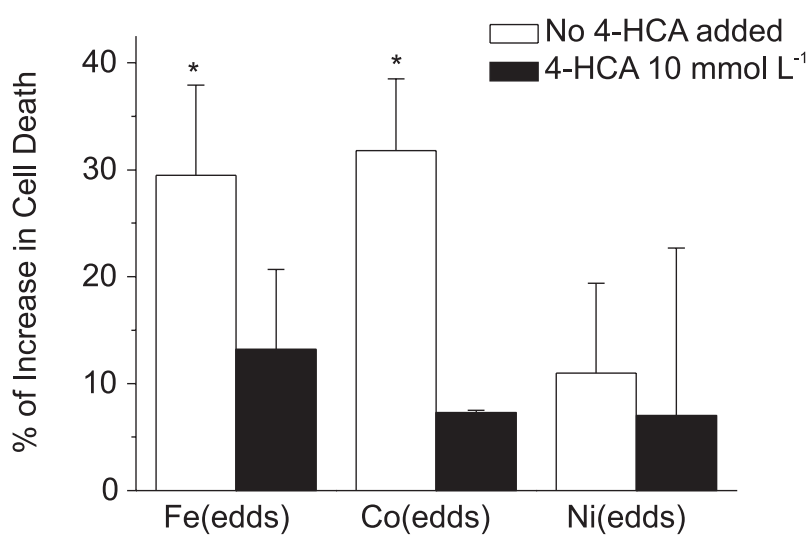

Figure 5. Increase of K562 mortality in relation to controls promoted by $100 \mu \mathrm{mol} \mathrm{L}^{-1} \mathrm{M}$-edds $(\mathrm{M}=\mathrm{Fe}, \mathrm{Co}, \mathrm{Ni})$ in the presence or absence of 10 mmol L-1 4-HCA (mean \pm S.D.) in PBS. Asterisks indicate significant differences from the control according to analysis of variance (ANOVA, $p<0.05$ ) and comparison of the groups using Fisher's LSD test (Protected t-Test). The Trypan Blue exclusion test was used to evaluate cell viability.

The mechanisms by which metal ions cause cell cycle arrest are not fully understood, since cell cycle regulation is a complex process with several steps, which is prone to interference by contaminants. Induction of apoptosis in tumor cells is an important strategy for the development of improved platinum-based metallodrugs. However, the biological response to these drugs seems to be dependent on both the cell line and the metal complex structure. ${ }^{34}$ For instance, vanadium compounds have been shown to induce both apoptosis and $\mathrm{S}$ phase arrest ${ }^{35}$ depending on the experimental model. Exogenous chelators also interfere with the cell cycle, the best known examples coming from studies of siderophores employed in iron chelation therapy, which may exert useful antitumoral effects by deactivating the metalloenzyme ribonucleotide reductase and inducing G1/S arrest. ${ }^{36}$

As with the previous results (Figure 2), we observed that cell mortality (apoptosis) was higher for K562 cells irrespective of the treatment (Figure 6 and Electronic Supplementary Information), which indicates that at least some tumor cell lines are less capable than normal cells of coping with the stress presented by the metal complexes. 
In both $\mathrm{K} 562$ and PBMC, the free acid edds induced a significant phase-specific arrest (G0/G1 in PBMC and $\mathrm{S}$ in K562). K562 cells treated with Mn-edds showed a decreased population in the $\mathrm{G} 2$ phase as compared to the control, which may be due to the slightly increased number of dead cells and/or cells in other phases.

Leukemic cell lines such as K562 are susceptible to a number of inducers of apoptosis, and a fraction of terminally differentiated cells undergo apoptosis during maturation as well. ${ }^{37}$ Our data corroborate these findings, in the sense that K562 cells were more sensitive to M-edds toxicity than PBMC cells in all cases.

The G1 checkpoint controls the progression through the cell cycle by checking for cell size, presence of growth factors, presence of nutrients and DNA damage. Progression to the $\mathrm{S}$ phase occurs after proteins of the $\mathrm{Rb}$ family are phosphorylated and unbound from E2F transcription factors in the DNA molecule. Cells with damaged DNA are prevented from progressing to the $\mathrm{S}$ phase by the $\mathrm{p} 53$

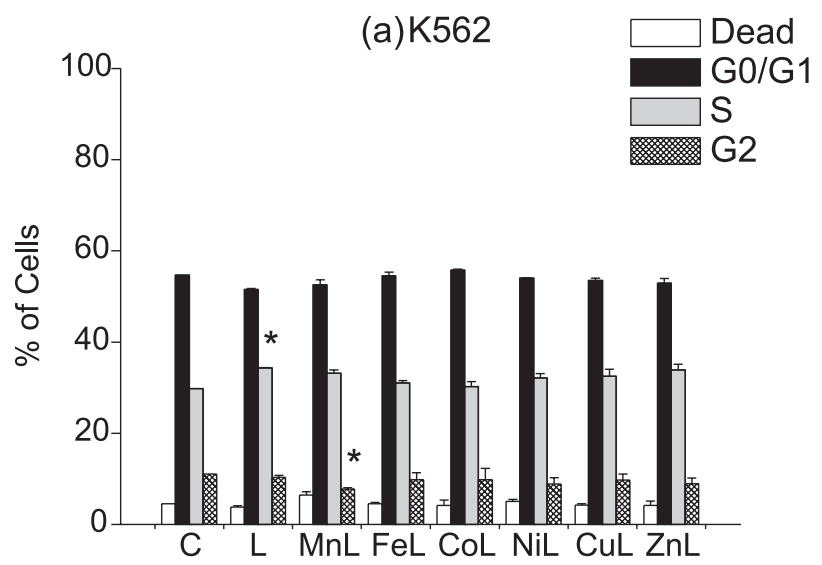

(b) PBMC

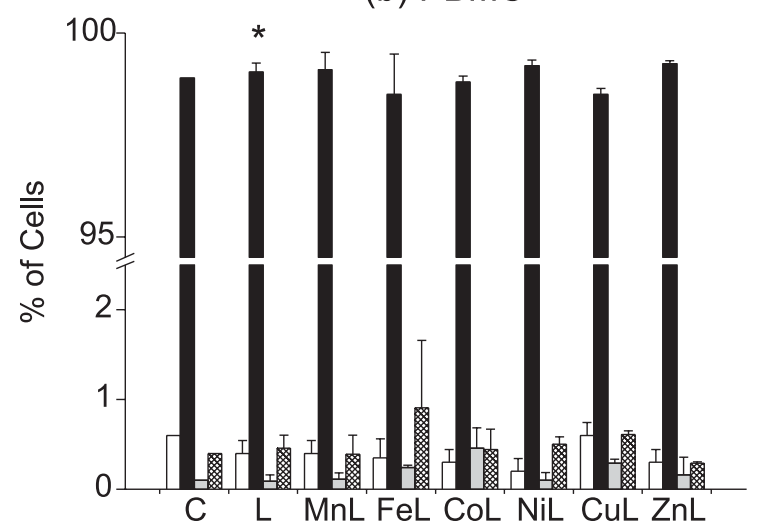

Figure 6. Cell cycle arrest induced by different M-edds complexes of K562 and PBMC cells after $1 \mathrm{~h}$ treatments (mean \pm S.D.) in complete RPMI medium. $\mathrm{C}=$ control; $\mathrm{L}=$ edds ; [edds] $=$ [M-edds $]=10 \mu \mathrm{mol} \mathrm{L}{ }^{-1}$. Asterisks indicate significant differences from the control according to analysis of variance (ANOVA, $p<0.05$ ) and comparison of the groups using Fisher's LSD test (Protected t-Test). protein which, among other roles, blocks Rb phosphorylation. ${ }^{38}$ Our results suggest that edds alone, and possibly Mn-edds, might either induce direct DNA damage or block p53 activity in K562 leukemic cells. Further experiments, e.g. an evaluation of nucleotide excision fragments or impaired expression of the p53 protein, and the role of edds in relation to zinc-finger transcription factors, should be performed in order to uncover the precise mechanism of action of these metal complexes.

\section{Conclusions}

Biodegradable ethylenediamminedisuccinic acid (edds) has been proposed as an environmentally friendly alternative to persistent edta for heavy metal remediation and decontamination. The biological activities studied here suggest that this acid is not toxic per se to human cells, and the toxicity of M-edds complexes is dependent upon the nature of M. The toxicity of Fe-edds may, in part, be due to its ability to induce redox reactions, although other models of oxidative damage (lipid peroxidation, DNA damage) should be investigated. Monocarboxylate transporters may be involved in the internalization of M-edds complexes. In our study, M-edds complexes also displayed some anti-proliferative activity, which should be explored further for the development of new metallodrugs for cancer chemotherapy.

\section{Acknowledgements}

This research was funded in part by CNPq (Brazilian Council for Scientific and Technological Development) and FAPESP (São Paulo State Council for Scientific Research). Octel Performance Chemicals kindly provided us with a sample of edds. Dr. Heraldo Possolo de Souza (School of Medicine, University of São Paulo) kindly permitted the use of the fluorescence microplate reader.

\section{Supplementary Information}

Cell cycle arrest induced by different M-edds complexes of K562 and PBMC cells after $1 \mathrm{~h}$ treatments (mean \pm S.D.) in complete RPMI medium. $\mathrm{C}=$ control; $\mathrm{L}=$ edds ; [edds $]=[\mathrm{M}$-edds $]=1,100$ and $1000 \mu \mathrm{mol} \mathrm{L}^{-1}$. Supplementary data are available free of charge at http://jbcs.sbq.org.br as PDF file.

\section{References}

1. Schowanek, D.; Feijtel, T. C. J.; Perkins, C.M.; Hartman, F. A.; Federle, T. W.; Larson, R. J.; Chemosphere 1997, 34, 2375. 
2. Bucheli-Witschel, M.; Egli, T.; FEMS Microbiol. Rev. 2001, $25,69$.

3. Hauser, L.; Tandy, S.; Schulin, R.; Nowack, B.; Environ. Sci. Technol. 2005, 39, 6819.

4. Kos, B.; Lestan, D.; Environ. Pollut. 2004, 132, 333.

5. Kos, B.; Lestan, D.; Environ. Sci. Technol. 2003, 37, 624.

6. Finzgar, N.; Kos, B.; Lestan, D.; Chemosphere 2004, 57, 655.

7. Meers, E.; Ruttens, A.; Hopgood, M. J.; Samson, D.; Tack, F. M. G.; Chemosphere 2005, 58, 1011.

8. Luo, C. L.; Shen, Z.G.; Li, X. D.; Chemosphere 2005, 59, 1.

9. Orama, M.; Hyvonen, H.; Saarinen, H.; Aksela, R.; J. Chem. Soc., Dalton Trans. 2002, 4644.

10. Jones, P. W.; Williams, D.R.; Appl. Radiat. Isot. 2001, 54, 587.

11. Jaworska, J. S.; Schowanek, D.; Feijtel, T. C. J.; Chemosphere 1999, 38, 3597.

12. Toney, J. H.; Koh, M. L.; JALA 2006, 11, 30.

13. Vogel, J. U.; Michaelis, M.; Neyts, J.; Blaheta, R. A.; Snoeck, R.; Andrei, G.; De Clercq, E.; Rabenau, H. F.; Kreuter, J.; Cinatl, J.; Doerr, H.W.; Antiviral Res. 2002, 55, 179.

14. Van Devivere, P. C.; Saveyn, H.; Verstraete, W.; Feijtel, T. C. J.; Schowanek, D. R.; Environ. Sci. Technol. 2001, 35, 1765.

15. Esposito, B. P.; Breuer, W.; Sirankapracha, P.; Pootrakul, P.; Hershko, C.; Cabantchik, Z. I.; Blood 2003, 102, 2670.

16. Martell, A. E.; Smith, R. M.; Critical Stability Constants - vol. 1, Plenum Press: New York, 1974.

17. Nakamoto, K.; Infrared and Raman Spectra of Inorganic and Coordination Compounds Part B: Applications in Coordination, Organometallic, and Bioinorganic Chemistry, WileyInterscience: New York, 1986.

18. Kovaleva, I.; Mitrofanova, N.; Martynenko, L.; Russ. J. Inorg. Chem. 1992, 37, 41

19. Vasilev, V.; Zaitseva, G.; Sapronova, N.; Russ. J. Inorg. Chem. 1991, 36, 1225.

20. Samsonov, A.; Gorelov, I.; Russ. J. Inorg. Chem. 1972, 17, 1148.

21. Babich, V.; Gorelov, I.; J. Anal. Chem. USSR 1971, 26, 1736.
22. Halliwell, B.; Gutteridge, J.; Free radicals in biology and medicine, $3^{\text {rd }}$. ed., Oxford Science Publishers: Oxford, 1999.

23. Halliwell, B.; Gutteridge, Meth. Enzymol. 1990, 180, 1.

24. Graf, E.; Mahoney, J. R.; Bryant, R. G.; Eaton, J. W.; J. Biol. Chem. 1984, 259, 3620.

25. Buettner, G.; Jurkiewicz, B. In: Analysis of Free Radicals in Biological Systems; Favier, A., ed., Birkhäuser Verlag: Basel, 1995.

26. Esposito, B. P.; Najjar, R. Coord. Chem. Rev. 2002, 232, 137.

27. Yao, D. C.; Shi, W. B.; Gou, Y. L.; Zhou, X. R.; Aw, T. Y.; Zhou, Y. K.; Liu, Z. X.; Free Rad. Biol. Med. 2005, 39, 1385.

28. Zodl, B.; Zeiner, M.; Paukovits, P.; Steffan, I.; Marktl, W.; Ekmekcioglu, C.; Microchem. J. 2005, 79, 393.

29. Bui, B. V.; Kalloniatis, M.; Vingrys, A. J.; Invest. Ophth. Vis. Sci. 2004, 45, 584.

30. Lin, R. Y.; Vera, J. C.; Chaganti, R. S. K.; Golde, D. W.; J. Biol. Chem. 1998, 273, 28959.

31. Wang, X.; Levi, A. J.; Halestrap, A. P.; Am. J. Physiol.-Heart C. 1996, 39, H476.

32. Galic, S.; Schneider, H. P.; Broer, A.; Deitmer, J. W.; Broer, S.; Biochem. J. 2003, 376, 413.

33. Yokel, R. A.; Allen, D. D.; Ackley, D. C.; J. Inorg. Biochem. 1999, 76, 127.

34. Valentini, A.; Pucci, D.; Crispini, A.; Federici, G.; Bernardini, S.; Chem.-Biol. Interact. 2006, 161, 241.

35. Leonard, S. S.; Bower, J. J.; Shi, X. L.; Mol. Cell. Biochem. 2004, 255, 3.

36. Kalinowski, D. S.; Richardson, D. R.; Pharmacol. Rev. 2005, $57,547$.

37. Tsiftsoglou, A. S.; Pappas, I. S.; Vizirianakis, I. S.; Pharmacol. Ther. 2003, 100, 257.

38. Macaluso, M.; Montanari, M.; Giordano, A.; Oncogene 2006, 25,5263 .

Received: December 21, 2006

Published on the web: January 28, 2008

FAPESP helped in meeting the publication costs of this article. 


\section{Biological Activity of Metal-edds (ethylenediaminedisuccinate) Complexes in $\mathrm{K} 562$ and PBMC Cells}

Natália J. S. Costa, ${ }^{a}$ Szulim B. Zyngier, ${ }^{b}$ Cíntia R. Bombardieri, ${ }^{b}$ Juliana S. Kuribayashi, ${ }^{b}$ Maristela M. de Camargo ${ }^{b}$ and Breno P. Espósito ${ }^{a, *}$

anstituto de Química, Universidade de São Paulo, Av. Lineu Prestes 748 sala 1265, 05508-000, São Paulo-SP, Brazil ${ }^{b}$ Instituto de Ciências Biomédicas, Universidade de São Paulo, Av. Lineu Prestes 2415, 05508-000, São Paulo-SP, Brazil
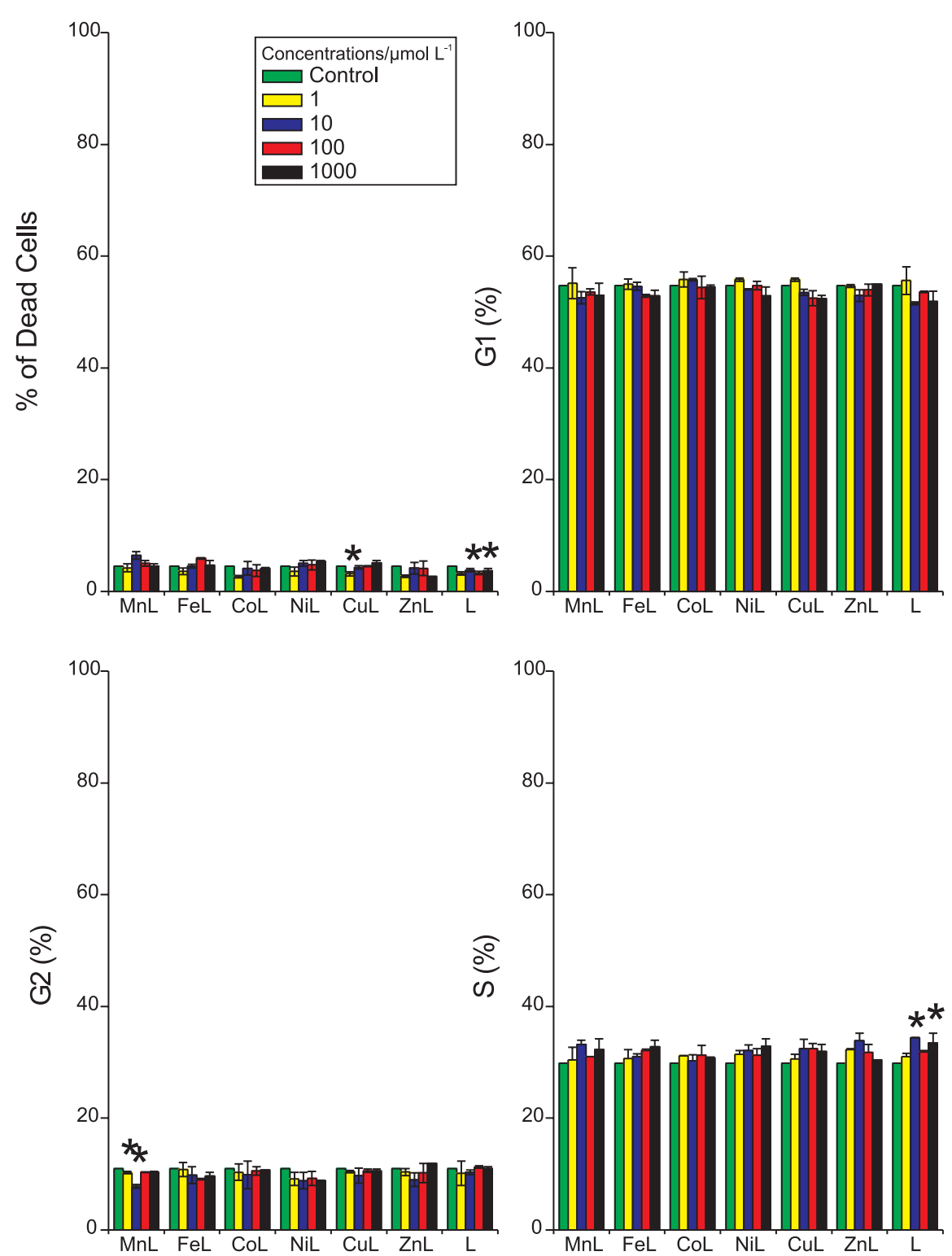

Figure S1. K562, $1 \mathrm{~h}$ - Cell cycle arrest induced by different M-edds complexes on K562 cells after 1-h treatments (mean \pm S.D.) in complete RPMI medium. $\mathrm{L}=$ edds ; [edds $]=[\mathrm{M}$-edds $]=1-1000 \mu \mathrm{mol} \mathrm{L}^{-1}$. Asterisks indicate significant differences from the control according to analysis of variance (ANOVA, $\mathrm{p}<0.05$ ) and comparison of the groups using Fisher's LSD test (Protected t-Test). 

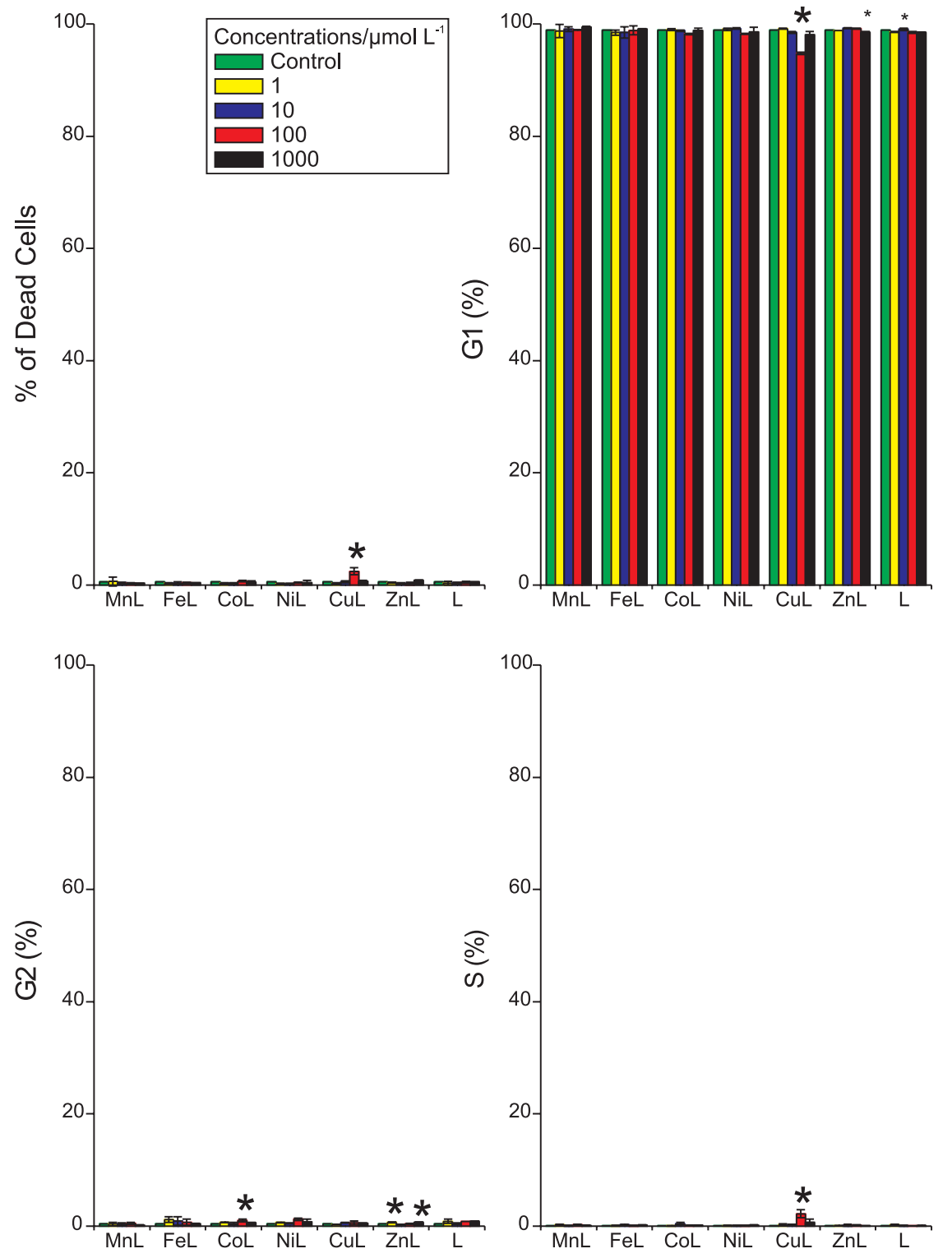

Figure S2. PBMC, $1 \mathrm{~h}-$ Cell cycle arrest induced by different M-edds complexes on PBMC cells after 1-h treatments (mean \pm S.D.) in complete RPMI medium. $\mathrm{L}=$ edds ; [edds $]=[\mathrm{M}$-edds $]=1-1000 \mu \mathrm{mol} \mathrm{L} \mathrm{L}^{-1}$. Asterisks indicate significant differences from the control according to analysis of variance (ANOVA, $\mathrm{p}<0.05)$ and comparison of the groups using Fisher's LSD test (Protected t-Test). 